\title{
PENGEMBANGAN SOAL MATEMATIKA MODEL PISA LEVEL 5 UNTUK PROGRAM PENGAYAAN SMP
}

\author{
${ }^{1)}$ Ambarsari Kusuma Wardani , ${ }^{2)}$ Zulkadi, ${ }^{3)}$ Yusuf Hartono \\ ${ }^{1,2,3)}$ Universitas Sriwijaya, Palembang \\ 1)ambarkusuma28@yahoo.com, ${ }^{2}$ zulkardi@yahoo.com, ${ }^{3)}$ y.hartono@unsri.ac.id
}

\begin{abstract}
This study aims to develop a valid and practical level 5 of PISA-like problem for enrichment program for seventh grade students. This is a development studies with formative evaluation type. Data collection techniques include walk through, documentation, interviews, questionnaires, and tests. The protoype is valid qualitatively by validators that are experts. In addition, experts have also stated that protoype is practical problems for. It has also been tested to know the quantitative validity and reliability of each items.
\end{abstract}

Keywords : Level 5 of PISA-like problem, Development Studies, Enrichment Program

\begin{abstract}
Abstrak
Penelitian ini bertujuan untuk mengembangkan soal matematika model PISA level 5 untuk program pengayaan siswa kelas VII yang valid dan praktis. Metode penelitian ini adalah penelitian pengembangan dengan tipe formative evaluation. Teknik pengumpulan data yang digunakan meliputi walk through, dokumentasi, wawancara, tes dan angket. Soal dinyatakan valid secara kualitatif oleh validator yang merupakan para pakar dan teman sejawat. Selain itu para pakar juga telah menyatakan bahwa perangkat soal telah praktis untuk digunakan siswa. Perangkat soal juga telah diujicobakan untuk melihat validitas dan reliabilitasnya secara kuantitatif.
\end{abstract}

Kata Kunci : Soal Matematika Model PISA Level 5, Penelitian Pengembangan, Program Pengayaan

\section{PENDAHULUAN}

Program for International Student Assessment (PISA) merupakan studi internasional yang diselenggarakan negara-negara yang tergabung dalam OECD (Organization for Economic Co-operation and Development). PISA dilakukan secara berkala yaitu tiga tahun sekali. Studi ini meneliti siswa usia 15 tahun dalam kemampuan membaca (reading literacy), matematika (mathematical literacy), sains (scientific literacy), finansial (financial literacy) dan pemecahan masalah (problem solving) (OECD, 2013).

Pada PISA 2012, kemampuan literasi matematika didefinisikan sebagai kemampuan siswa dalam merumuskan, menggunakan dan menafsirkan matematika 
dalam berbagai konteks. Kemampuan literasi ini termasuk penalaran matematis dan menggunakan konsep-konsep matematika, prosedur, fakta dan alat-alat untuk menggambarkan, menjelaskan dan memprediksi fenomena. Ini membantu siswa untuk mengenali peran matematika di dunia dan untuk membuat keputusan yang beralasan (OECD, 2013). Seseorang siswa dikatakan memiliki tingkat literasi matematika baik apabila ia mampu menganalisis, bernalar, dan mengkomunikasikan pengetahuan dan keterampilan matematikanya secara efektif, serta mampu memecahkan dan menginterpretasikan masalah matematika. Sehingga, pengetahuan dan pemahaman mengenai literasi matematika sangat penting bagi siswa.

Stacey (2011) menyatakan bahwa presentase skor kemampuan literasi matematika siswa Indonesia pada PISA 2009 dalam menjawab soal level 5 sangat kecil jika dibandingkan dengan negara lain. Sejalan dengan hal tersebut, analisis hasil PISA 2003-2009 menunjukkan bahwa sebagian besar siswa Indonesia tidak mampu menyelesaikan permasalahan matematika level tinggi (Widjaja, 2011). Hal ini menjadi salah satu dasar pemikiran pengembangan Kurikulum 2013. Tujuan dari Kurikulum 2013 salah satunya adalah agar siswa memperoleh pembelajaran yang sesuai dengan soal yang diujikan di tingkat internasional (Kemdikbud, 2013). Maka dari itu, pembelajaran matematika siswa disajikan dengan masalah-masalah kontekstual yang merujuk pada soal model PISA.

Tetapi, pada kenyataannya siswa Indonesia belum terbiasa menyelesaikan soal kontekstual terlebih lagi soal model PISA level tinggi (Kamaliyah, 2012). Hal ini disebabkan sebagian besar tes item evaluasi pada proses pembelajaran matematika belum menggunakan soal level tinggi (Novita, 2012). Rizta (2013) menyatakan bahwa guru enggan memberikan soal level tinggi karena dianggap akan menghabiskan waktu lebih banyak pada proses pembelajaran. Sehingga sebagian besar latihan soal yang diberikan pada proses pembelajaran masih berupa soal prosedural, karena mengacu pada tes sumatif dengan bentuk tes serupa. Oleh karena itu, siswa membutuhkan aktivitas belajar selain dari pembelajaran biasa guna mendapatkan pengalaman belajar mengenai soal level tinggi.

Pemberian soal level tinggi kepada siswa salah satunya yaitu melalui program pengayaan. Secara umum pengayaan dapat diartikan sebagai pengalaman atau kegiatan peserta didik yang melampaui persyaratan minimal yang ditentukan oleh kurikulum dan 
tidak semua peserta didik dapat melakukannya, dengan kata lain pengayaan diberikan bagi peserta didik yang mencapai ketuntasan belajar lebih awal (Lalley \&Gentile: 2003).

Jika ada peserta didik yang lebih mudah dan cepat mencapai penguasaan kompetensi minimal yang ditetapkan, maka sekolah perlu memberikan perlakuan khusus berupa program pengayaan.Beecher dan Sweeny (2008) menyatakan bahwa pembelajaran pada program pengayaan cakupan materinya lebih luas dan mendalam dibandingkan dengan pembelajaran biasa. Oleh karena itu, pembelajaran pengayaan memberikan kesempatan kepada peserta didik yang memiliki kecerdasan lebih dengan tantangan belajar yang lebih tinggi untuk membantu mereka mencapai kapasitas optimal dalam belajar.

Program pengayaan didesain untuk mengembangkan kemampuan berpikir tingkat tinggi siswa dengan pemberian masalah level tinggi (McAllister \& Plourde, 2008). Hal ini sesuai dengan tiga jenis pembelajaran pengayaan yang salah satunya dapat melalui pemberian soal pemecahan masalah atau permasalahan dunia nyata (Renzulli \& Reis, 2005, Depdiknas, 2008). Wheeler dan Haertel mengatakan bahwa kemampuan berpikir tingkat tinggi dapat dikembangkan melalui kegiatan pemecahan masalah yang mengeksplorasi kemampuan berargumen, membandingkan, mengevaluasi, mengambil keputusan dan menarik kesimpulan (Forster, 2004). Soal pemecahan masalah yang diberikan pada pengayaan yaitu soal yang mengacu pada permasalahan dari dunia nyata (Rule, Schneider, Tallakson, \& Highnam, 2012). Permasalahan dunia nyata dengan level tinggi sejalan dengan soal model PISA level tinggi pula. Soal PISA level tinggi dapat berupa soal PISA level 5. Masalah-masalah yang diberikan kepada siswa pada program pengayaan dapat berupa masalah-masalah soal model PISA. Berikut disajikan pada tabel 1 mengenai karakteristik soal pengayaan yang sejalan dengan karakteristik soal PISA level tinggi.

Tabel 1. Karakteristik soal pengayaan dan soal model PISA

\begin{tabular}{|c|c|c|}
\hline No. & Karakteristik Soal Pengayaan & Karakteristik Soal PISA \\
\hline 1. & $\begin{array}{l}\text { Mengacu pada permasalahan dunia } \\
\text { nyata (Rule dkk, 2012) }\end{array}$ & Mengacu pada konteks dunia nyata. \\
\hline 2. & $\begin{array}{lr}\text { Mengembangkan } & \text { kemampuan } \\
\text { representasi dari } & \text { masalah menuju } \\
\text { ke } \quad \text { model } & \text { matematika }\end{array}$ & $\begin{array}{l}\text { Bekerja secara efektif dengan model } \\
\text { dalam situasi yang kompleks }\end{array}$ \\
\hline
\end{tabular}




\begin{tabular}{|c|c|c|}
\hline No. & Karakteristik Soal Pengayaan & Karakteristik Soal PISA \\
\hline & (Renzulli\&Reis, 2008) & \\
\hline 3. & $\begin{array}{l}\text { Mengembangkan kemampuan } \\
\text { dalam mengkomunikasikan } \\
\text { penjelasan dan argumen dalam } \\
\text { pemilihan strategi penyelesaian } \\
\text { masalah (Renzulli\&Reis, 2008) }\end{array}$ & $\begin{array}{l}\text { Membangun } \\
\text { mengkomunikasikan pendapat dan } \\
\text { interpretasi dari masalah } \\
\text { Mampu memilih dan mengevaluasi } \\
\text { strategi penyelesaian yang sesuai } \\
\text { untuk tiap masalah }\end{array}$ \\
\hline 4. & $\begin{array}{l}\text { Melakukan penarikan kesimpulan } \\
\text { berdasarkan hasil investigasi } \\
\text { (Renzulli\&Reis, 2008) }\end{array}$ & \begin{tabular}{lcc} 
Melakukan & \multicolumn{2}{c}{ konseptualisasi dan } \\
generalisasi menggunakan informasi \\
berdasarkan investigasi terhadap \\
masalah
\end{tabular} \\
\hline 5. & $\begin{array}{l}\text { Memberikan kesempatan untuk } \\
\text { merefleksi tindakan yang } \\
\text { dilakukan dalam penyelesaian } \\
\text { masalah dan menginterpretasikan } \\
\text { dengan baik hasil dari refleksi } \\
\text { tersebut (Renzulli\&Reis, 2008) }\end{array}$ & $\begin{array}{l}\text { Merefleksi dan mempertimbangkan } \\
\text { temuan dalam penyelesaian masalah } \\
\text { dan mengkomunikasikan interpretasi } \\
\text { dan pendapatnya }\end{array}$ \\
\hline
\end{tabular}

Soal PISA memiliki tingkatan atau level tersendiri. Pada tiap level, terdapat kriteria yang menggambarkan kemampuan siswa. Tabel 2 berisi deskripsi mengenai level 5 soal PISA yang digunakan pada tahun 2003, 2006 dan 2009. Level ini merupakan bentuk dasar dari level PISA 2012.

Tabel 2. Level dalam PISA

\begin{tabular}{|c|c|}
\hline Level & Aktivitas yang dilakukan siswa \\
\hline Level 5 & $\begin{array}{l}\text { - Siswa dapat mengembangkan dan bekerja dengan model pada } \\
\text { situasi yang komplek, mengidentifikasi kendala dan menjelaskan } \\
\text { dengan tepat dugaan-dugaan. } \\
\text { - Siswa memilih, membandingkan dan mengevaluasi strategi } \\
\text { penyelesaian masalah yang sesuai ketika berhadapan dengan } \\
\text { situasi yang rumit yang berhubungan dengan model tersebut. } \\
\text { - Siswa bekerja dengan menggunakan pemikiran dan penalaran } \\
\text { yang luas, serta secara tepat menghubungkan pengetahuan dan } \\
\text { ketrampilan matematikanya dengan situasi yang dihadapi. } \\
\text { - Siswa dapat melakukan refleksi dari apa yang mereka kerjakan } \\
\text { dan mengkomunikasikan interpretasi dan penelarannya. }\end{array}$ \\
\hline
\end{tabular}

Salah satu upaya untuk memaksimalkan aktivitas-aktivitas siswa sesuai dengan kriteria soal PISA level 5 adalah dengan membiasakan siswa dengan soal tersebut.Agar siswa terbiasa dengan soal model PISA level 5, maka dapat dilakukan dengan pemberian soal tersebut sedini mungkin atau pada awal siswa menginjak jenjang sekolah menengah (Barczi, 2008). Maka dari itu ada banyak penelitian yang 
mengembangkan soal model PISA di Sekolah Menengah Pertama dengan berbagai fokus seperti Edo (2012) mengembangkan soal model PISA yang mengukur kemampuan pemodelan siswa. Ahyan (2012) mengembangkan soal matematika model PISA dengan konten change and relationship dan Lutfianto (2013) mengembangkan soal matematika model PISA konteks pribadi. Serta Mangelep (2013) telah mengembangkan soal model PISA pada kompetensi proses koneksi dan refleksi. Hingga saat ini belum ada yang mengembangkan soal model PISA dengan framework 2012 untuk diberikan pada program pengayaan, terlebih lagi diterapkan pada Kurikulum 2013. Berdasarkan uraian sebelumnya, maka tujuan dari penelitian ini untuk mengembangkan soal matematika model PISA level 5 untuk program pengayaan siswa kelas VII yang valid dan praktis.

\section{METODE PENELITIAN}

Metode dalam penelitian ini adalah metode penelitian design research dengan tipe development studies atau penelitian pengembangan. Penelitian ini terdiri dari dua tahap yakni preliminary atau persiapan dan tahap prototyping (formative evaluation) yang meliputi self evaluation, expert reviews dan one-to-one dan small group serta field test (Tessmer 1993, Zulkardi 2002).

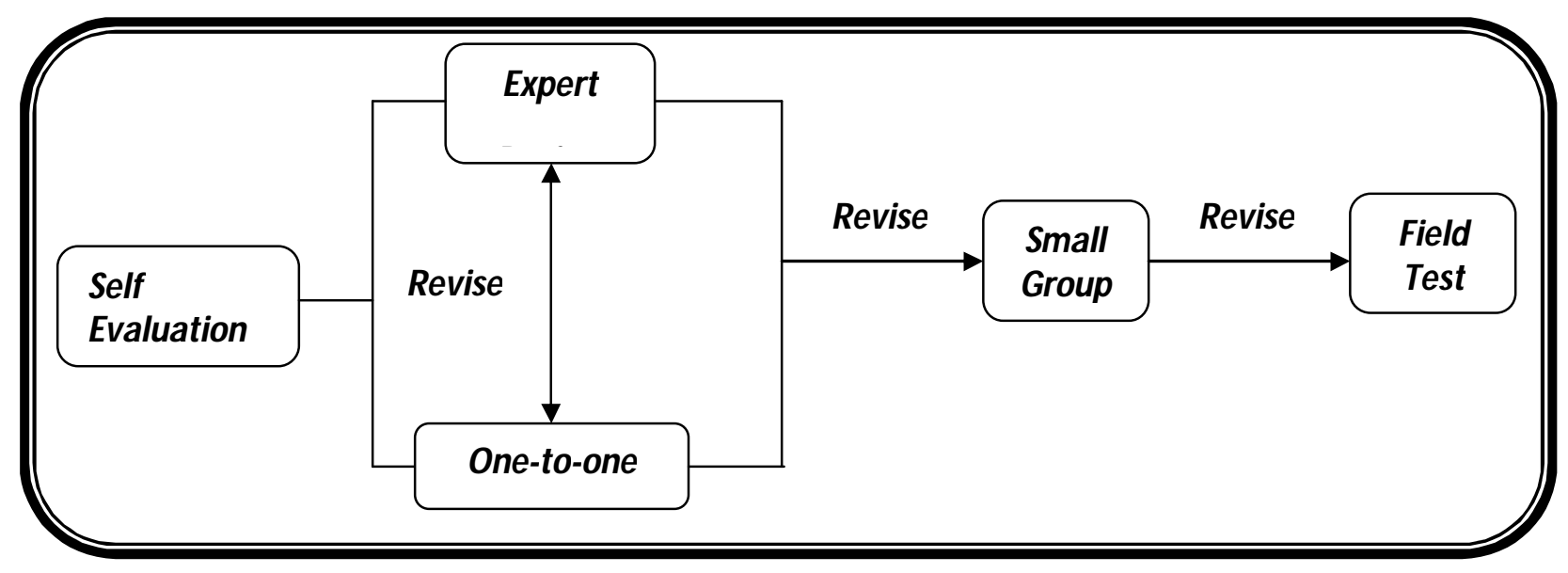

Gambar 1.Alur desain formative evaluation

Pada tahap preliminary, peneliti melakukan analisis siswa, analisis kurikulum, dan analisis soal PISA sebagai dasar untuk mengembangkan soal. Selanjutnya peneliti mendesain draf protoype awal dari soal yang akan dikembangkan serta membuat perangkat instrumen pengembangan soal. 
Tahap kedua yaitu tahap prototyping, yang diawali dengan tahap self evaluation. Pada tahap ini, peneliti menelaah kembali dan mengevaluasi draf awal perangkat soal yang telah didesain hingga menghasilkan protoype I. Selanjutnya protoype I diujicobakan pada tahap expert review dan one-to-one secara paralel.

Pada tahap expert review, protoype I divalidasi secara konten, konstruk dan bahasa dengan menggunakan walk through oleh para pakar dalam dan luar negeri dan teman sejawat.

Tabel 3. Karakteristik yang menjadi fokus protoype

\begin{tabular}{lll}
\hline No. & Karakteristik & \multicolumn{1}{c}{ Keterangan } \\
\hline 1. & Konten & Soal sesuai dengan ciri PISA \\
& & Soal sesuai dengan kriteria soal PISA level 5 \\
\hline 2. & Konstruk & Soal sesuai dengan teori dan kriteria. \\
& & - Mengembangkan literasi matematika siswa. \\
& & - Kaya dengan konsep \\
& & - Sesuai dengan level siswa kelas VII SMP. \\
& & - Mengundang pengembangan konsep lebih lanjut \\
& & - Sesuai dengan framework PISA \\
& & Sesuai dengan karakteristik soal pengayaan \\
\hline 3. & Konstruk & Sesuai dengan EYD. \\
& & Soal tidak berbelit-belit. \\
& & Soal tidak mengandung penafsiran ganda. \\
& & Batasan soal dan pertanyaan jelas \\
\hline
\end{tabular}

Bersamaan dengan expert review, one-to-one dilakukan pada empat siswa dengan nilainya telah melewati standar kriteria ketuntasan minimal (KKM) yang telah ditetapkan sekolah. Uji coba one-to-one berfokus pada kejelasan, kemudahan penggunaan, kepraktisan protoype yang dikembangkan, dan ketertarikan siswa terhadap soal yang diberikan. Hasil revisi expert review dan one-to-one menghasilkan protoype 2 yang akan diujikan pada tahap selanjutnya yaitu small group.

Tahap small group dilakukan pada 12 siswa. Siswa-siswa yang terlibat pada tahap ini merupakan siswa dengan kemampuan matematika yang beragam, dengan nilai matematika melebihi KKM. Setelah mengerjakan protoype 2, siswa mengisi lembar angket dan selanjutnya dilakukan wawancara langsung untuk menggali komentar dan saran siswa guna mengetahui kepraktisan soal. Pada tahap ini juga dilakukan analisis butir soal untuk menguji validitas dan reliabilitas butir soal. Hasil revisi soal yang dilakukan berdasarkan saran/komentar siswa dan analisis butir soal pada tahap small group, maka dihasilkan protoype 3 yang diujikan pada tahap field test. Pada tahap field 
test, protoype 3 diujicobakan pada subjek penelitian yaitu siswa kelas 7.A SMPK Frater Xaverius I sebanyak 20 siswa.

Teknik pengumpulan data yang digunakan adalah dokumentasi, walk through, tes, wawancara, dan angket. Teknik pengumpulan data melalui dokumentasi dilakukan pada tahap self evaluation, yaitu dokumen yang digunakan adalah Kurikulum 2013 untuk sekolah menengah pertama, framework PISA dan soal-soal PISA. Kemudian peneliti mendesain soal model PISA beserta perangkatnya yang meliputi kisi-kisi dan soal matematika model PISA level 5, dengan menggunakan karakteristik konten/isi, konstruk dan bahasa sehingga diperoleh soal protoype 1.

Pada tahap expert review, walk through dilakukan dengan pakar. Pakar memberikan masukan/komentar atau saran terkait dengan konten, konstruk dan bahasa. Dari hasil walk through digunakan untuk revisi protoype pertama yang akan digabungkan dengan uji one-to-one untuk mendapatkan protoype kedua.

Pada tahap field test, protoype ketiga diteskan kepada siswa yang telah ditentukan. Hasil field test itu digunakan untuk mendapatkan data mengenai efek potensial soal pengayaan model PISA level 5 yang dikembangkan terhadap siswa SMP kelas VII.

Wawancara dilakukan kepada siswa setelah siswa selesai mengerjakan soal matematika model PISA pada tahap one-to-one, small group dan field test. Hasil wawancara di one-to-one dan small group digunakan sebagai bahan revisi pada protoype soal sedangkan hasil wawancara pada field test digunakan untuk menggali informasi mengenai efek potensial soal terhadap kemampuan matematika siswa. Untuk membantu dalam proses wawancara maka dibutuhkan video atau rekaman pada saat wawancara berlangsung.

Pemberian angket dilakukan setelah one-to-one, small group, dan field test. Pada tahap one-to-one dan small group angket digunakan untuk mengetahui komentar dan saran siswa terhadap soal. Sedangkan pada tahap field test, angket digunakan untuk menggali efek potensial soal terhadap kemampuan matematika siswa. Jika wawancara hanya dilakukan pada beberapa siswa maka angket diberikan kepada semua siswa yang menjadi subjek penelitian di field test .

\section{HASIL DAN PEMBAHASAN}

Tahap Preliminary 
Pada tahap ini dilakukan analisis siswa, analisis kurikulum serta analisis terhadap soal-soal PISA. Analisis siswa dilakukan berdasarkan pada analisis kemampuan siswa. Sesuai dengan tujuan penelitian yaitu pengembangan soal model PISA untuk program pengayaan, sehingga siswa yang dipilih adalah siswa yang nilai matematikanya melampaui standar ketuntasan yang telah ditentukan sekolah. Sehingga dipilih siswa dari tiga kelas yang berbeda untuk tahap prototyping, yaitu 4 orang siswa dari kelas 7.B untuk tahap one-to-one, 12 orang siswa dari kelas 7.G untuk tahap small group dan 20 orang siswa dari kelas 7.A untuk tahap field test.

Analisis kurikulum dilakukan untuk mengkaji materi pembelajaran matematika SMP kelas VII semester I yang digunakan sebagai acuan dalam pengembangan soal PISA nantinya. Kurikulum yang digunakan sebagai acuan dalam penelitian ini adalah Kurikulum 2013. Pada Kurikulum 2013, pembelajaran pengayaan dapat berupa perluasan materi dari kompetensi dasar yang telah diajarkan.

Analisis soal dilakukan dengan mengidentifikasi karakteristik soal PISA matematika level tinggi yang sejalan dengan karakteristik soal pengayaan yaitu soal level 5. Analisis soal meliputi analisis konten, konteks, dan level kemampuan matematika dalam PISA. Berdasarkan hasil analisis soal PISA dan review dari berbagai sumber mengenai PISA, peneliti mendapatkan informasi yang terperinci mengenai karakteristik maupun kesesuaian soal-soal PISA dengan kurikulum matematika tingkat SMP di Indonesia.

Selanjutnya pada tahap persiapan, dilakukan pendesainan draf protoype awal dari soal yang akan dikembangkan. Pada tahap awal ini peneliti juga menghasilkan perangkat instrumen pengembangan soal yaitu, kisi-kisi soal, perangkat soal, kartu soal dan rubrik penilaian. Sehingga pada tahap preliminary telah ditentukan subjek penelitian, materi apa yang menjadi konten pada soal yang dikembangkan. Selanjutnya dilakukan pendesainan draf protoype awal dari soal yang akan dikembangkan. Pada tahap awal ini peneliti juga menghasilkan perangkat instrumen pengembangan soal yaitu, kisi-kisi soal, perangkat soal, kartu soal dan rubrik penilaian.

\section{Tahap Prototyping}

Tahap kedua desain penelitian ini adalah tahap prototyping dengan menggunakan alur formative evaluation. Adapun tahapan-tahapan yang dilakukan pada formative evaluation ini terdiri dari: 


\section{Self Evaluation}

Pada tahap self evaluation, peneliti menelaah kembali draf awal perangkat soal yang telah didesain. Draf soal tersebut dievaluasi kembali untuk melihat kesesuaian soal dari segi isi/konten, konstruk dan bahasa. Hasil evaluasi draf soal pada tahap self evaluation disebut protoype I (Gambar 2) dan hasil inilah yang akan divalidasi pada tahap expert review sekaligus diujikan kepada siswa pada tahap one-to-one.

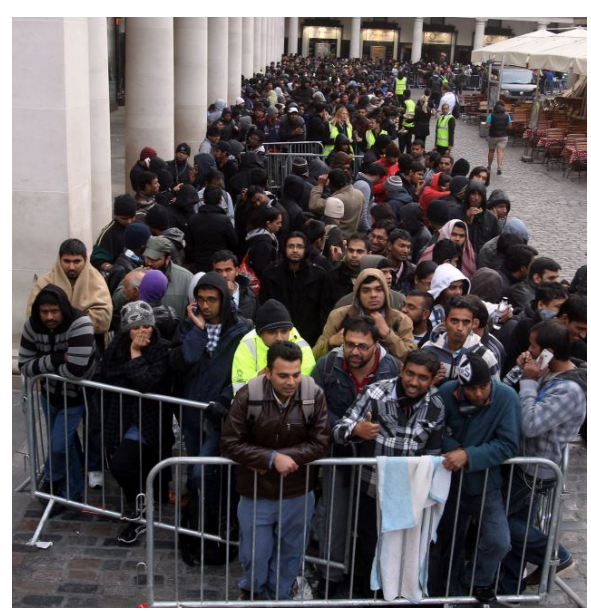

Sumber: www.jadiberita.com

Para pembeli penuh sesak memadati tempat antrian penjualan telepon pintar terbaru.

\section{Pertanyaan}

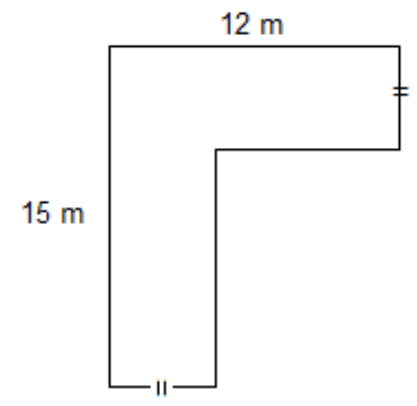

Dengan area mengantri yang tampak seperti pada gambar di $3 \mathrm{~m}$ samping, berapakah perkiraan jumlah calon pembeli yang antri tersebut?
a. 100
b. 500
c. 5000
d. 10000

Gambar 2.Soal Protoype 1

\section{Expert review}

Expert review atau uji pakar merupakan tahap validasi protoype I secara kualitatif yaitu ditinjau dari segi isi/konten, konstruk dan bahasa. Perangkat soal dikonsultasikan kepada para pakar dan teman sejawat yang sudah berpengalaman dalam pendidikan matematika sebagai validator. Proses validasi protoype I dilakukan melalui tiga cara, yaitu tatap muka (face-to-face review), surat/email (mails review), sidang panel (panel 
review) (Tessmer, 1993). Berikut nama-nama pakar sebagai validator yang terlibat pada tahap expert review.

Tabel 4. Validator pada tahap expert review

\begin{tabular}{|c|c|c|c|}
\hline $\begin{array}{l}\text { Proses } \\
\text { Validasi }\end{array}$ & Nama Pakar & Jabatan & Institusi \\
\hline \multirow[t]{3}{*}{$\begin{array}{l}\text { Mails } \\
\text { review }\end{array}$} & Prof. Kaye Stacey & Ketua MEG PISA & $\begin{array}{l}\text { University of } \\
\text { Melbourne, Australia }\end{array}$ \\
\hline & Dr. Ross Turner & $\begin{array}{l}\text { Direktur ACER, } \\
\text { Tim MEG PISA }\end{array}$ & $\begin{array}{l}\text { Australian Council for } \\
\text { Educational } \\
\text { Research/ACER, } \\
\text { Australia }\end{array}$ \\
\hline & Kamaliyah, M.Pd. & $\begin{array}{l}\text { Dosen } \\
\text { matematika, } \\
\text { Peneliti PISA }\end{array}$ & $\begin{array}{l}\text { Universitas Lambung } \\
\text { Mangkurat }\end{array}$ \\
\hline $\begin{array}{l}\text { Face-to } \\
\text {-face } \\
\text { review }\end{array}$ & Yuni, S.Pd & Guru matematika & $\begin{array}{l}\text { SMP K Frater } \\
\text { Xaverius } 1 \text { Palembang }\end{array}$ \\
\hline \multirow{2}{*}{$\begin{array}{l}\text { Mail \& } \\
\text { panel } \\
\text { review }\end{array}$} & $\begin{array}{l}\text { Prof. Dr. Ahmad } \\
\text { Fauzan }\end{array}$ & Dosen tim PMRI & $\begin{array}{l}\text { Universitas Negeri } \\
\text { Padang }\end{array}$ \\
\hline & $\begin{array}{l}\text { Prof. Dr. Ipung } \\
\text { Yuwono }\end{array}$ & Dosen tim PMRI & $\begin{array}{l}\text { Universitas Negeri } \\
\text { Malang }\end{array}$ \\
\hline \multirow[t]{4}{*}{$\begin{array}{c}\text { Panel } \\
\text { Review }\end{array}$} & Prof. R.K. Sembiring & Ketua PMRI & PMRI Pusat \\
\hline & Dr. Agung Lukito, MS. & Dosen tim PMRI & $\begin{array}{l}\text { Universitas Negeri } \\
\text { Surabaya }\end{array}$ \\
\hline & Yenita Roza, Ph.D. & Dosen tim PMRI & Universitas Riau \\
\hline & Dr. Sugiman, M.Pd. & Dosen tim PMRI & $\begin{array}{l}\text { Universitas Negeri } \\
\text { Yogyakarta }\end{array}$ \\
\hline
\end{tabular}

Pada tahap expert review, beberapa pakar menyarankan untuk melakukan revisi pada soal, yaitu menambahkan perintah pada soal agar siswa menjelaskan bagaimana proses yang dilakukan siswa dalam menemukan penyelesaian dari soal tersebut. Selain itu, pakar juga menyarankan untuk merevisi pilihan jawaban pada soal agar rentangnya lebih mendekati ke jawaban yang sebenarnya. Selanjutnya, revisi juga dilakukan terhadap gambar area mengantri yang dilampirkan pada soal dengan perbandingan ukuran yang tepat.

\section{One-to-one}

Uji one-to-one dilakukan bersamaan dengan uji pakar. Pada tahap uji coba oneto-one, soal protoype I diujicobakan kepada empat siswa. Keempat siswa yang 
melaksanakan uji one-to-one merupakan siswa yang nilainya telah melewati standar ketentuan kelulusan maksimal (KKM). Siswa diminta untuk mengerjakan protoype awal. Setelah mengerjakan soal, siswa diberikan angket yang terdiri dari beberapa pertanyaan mengenai soal yang telah dikerjakan. Selanjutnya peneliti mewawancarai siswa untuk mengkonfirmasi jawaban pada angket. Bersumber pada hasil angket dan wawancara siswa, maka dilakukan revisi pada soal yaitu gambar area mengantri diperbaiki dengan ukuran yang lebih tepat.

Berdasarkan hasil expert review dan uji one-to-one yang telah dilakukan secara paralel, maka soal protoype I direvisi kembali dan menghasilkan protoype 2. Adapun hasil revisi soal tersebut adalah sebagai berikut:

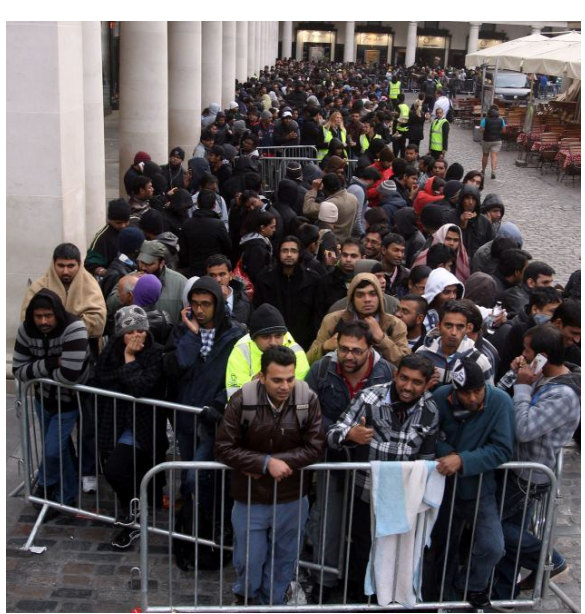

Sumber: $\underline{w w w . j a d i b e r i t a . c o m}$

Para pembeli penuh sesak memadati tempat antrian penjualan telepon pintar terbaru.

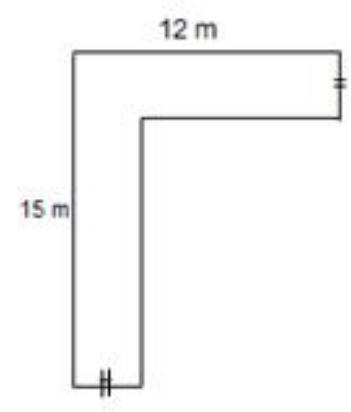

\section{Pertanyaan}

$3 \mathrm{~m}$ Dengan area mengantri yang tampak seperti pada gambar di samping, berapakah perkiraan jumlah calon pembeli yang antri tersebut?
a. 150
b. 750
c. 1500
d. 3000

Jelaskan jawabanmu.

\section{Small group}


Pada tahap small group, soal protoype 2 diujikan kepada 12 siswa. Siswa-siswa yang terlibat pada tahap ini merupakan siswa dengan kemampuan matematika yang beragam, dengan nilai matematika melebihi kriteria ketuntasan minimal (KKM) yang telah ditetapkan sekolah. Kedua belas siswa diminta untuk mengerjakan soal protoype 2.Selanjutnya, siswa diberikan angket yang berisi pertanyaan-pertanyaan yang terkait dengan soal yang telah dikerjakan. Setelah pengisian angket, peneliti melakukan wawancara untuk menggali komentar dan saran siswa mengenai soal tersebut.

Selain menganalisis jawaban siswa, angket dan hasil wawancara, peneliti melakukan analisis butir soal untuk menguji validitas dan reliabilitas butir soal. Analisis butir soal dilakukan dengan menggunakan perangkat lunak Microsoft Excel. Uji validitas butir soal menggunakan korelasi product moment dari Karl Pearson, dan untuk reliabilitas soal digunakan Cronbach-Alpha.Data dan hasil uji validitas butir soal ditunjukkan pada tabel 5 .

Tabel 5. Hasil uji validitas butir soal

\begin{tabular}{ccc}
\hline r-tabel & r-hitung & Keterangan \\
\hline 0,576 & 0,491 & Tidak Valid \\
\hline
\end{tabular}

Peneliti menggali penyebab ketidakvalidan soal dengan mewawancarai siswa kembali. Sehingga diperoleh informasi bahwa siswa telah mengerti dengan baik maksud soal, tetapi siswa tidak mengetahui penyelesaian soal tersebut, baik itu karena lupa atau karena siswa kurang memahami materi yang telah dipelajari sebelumnya. Selain dari itu, ketidakvalidan juga disebabkan fluktuatif skor jawaban yang terlalu besar, seperti soal pilihan ganda. Sehingga diputuskan untuk melakukan revisi terhadap skor jawaban dari soal tersebut pada rubrik penilaian. Sedangkan untuk hasil uji reliabilitas, soal yang diujicobakan tersebut didapatkan hasil koefisien reliabilitasnya sebesar 0,698. Dengan hasil koefisien yang telah didapat, soal protoype 2 dinyatakan memiliki reliabilitas yang tinggi.

Protoype 2 dinyatakan memeliki reliabilitas yang tinggi dan kevalidan yang rendah. Ini berarti bahwa soal yang diujicobakan memiliki kekonsistenan yang tinggi, tetapi tidak dapat dengan tepat mengukur kemampuan siswa. Hal ini disebabkan siswa tidak terbiasa dengan soal model PISA seperti yang diujicobakan. Siswa cenderung mengerjakan soal-soal prosedural pada pembelajaran biasa. Maka dari itu, soal model 
PISA yang dikembangkan ini diberikan pada program pengayaan untuk menambah pemahaman, pengetahuan dan pengalaman siswa dalam mengerjakan soal model PISA, hal ini sesuai dengan tujuan dari program pengayaan.

Hasil revisi soal yang dilakukan berdasarkan saran/komentar siswa dan analisis butir soal pada tahap small group, maka dihasilkan protoype ketiga yang tetap terdiri dari 14 soal yang akan diujikan pada tahap field test.

\section{Field test}

Pada tahap field test, hasil revisi soal pada tahap small group yakni protoype 3 diujicobakan pada subjek penelitian yaitu siswa SMPK Frater Xaverius 1 kelas 7.A sebanyak 20 siswa. Setelah mengerjakan soal, siswa diberi waktu 10 menit untuk mengisi angket dan beberapa siswa dipilih untuk diwawancara langsung oleh peneliti. Peneliti juga mengamati siswa dalam mengerjakan soal, sehingga dapat diketahui kesulitan-kesulitan apa saja yang siswa alami.

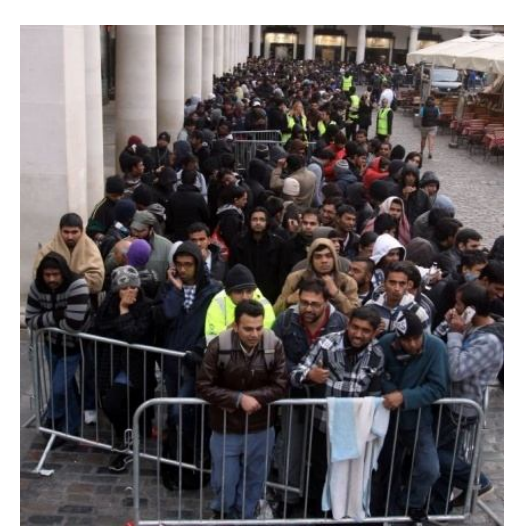

Sumber: www.jadiberita.com

Para pembeli penuh sesak memadati tempat antrian penjualan smartphone terbaru.

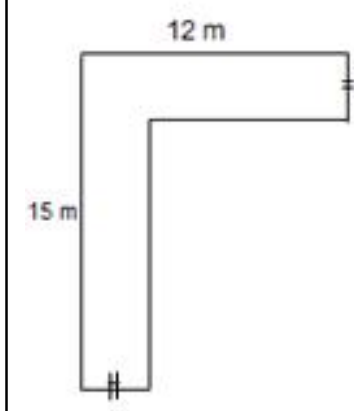

\section{Pertanyaan 2.}

Dengan area mengantri yang tampak seperti pada gambar di $3 \mathrm{~m}$ samping, berapakah perkiraan jumlah calon pembeli yang antri tersebut?
a. 150 orang
b. 750 orang
c. 1500 orang
d. 3000 orang

Jelaskan jawabanmu. 


\section{Pembahasan}

Berdasarkan proses pengembangan soal yang telah melalui beberapa tahapan dimulai dari tahap persiapan (preliminary) hingga tahap prototyping dengan alur formative evaluation yang meliputi self evaluation, expert review, one-to-one, small group, dan field test, telah dihasilkan soal model PISA untuk program pengayaan dengan level 5. Soal-soal tersebut telah dinyatakan valid secara kualitatif dan praktis.

Kevalidan soal secara kualitatif ditunjukkan dari hasil penilaian validator pada tahap expert review yang menyatakan bahwa soal telah baik dari segi konten yaitu sesuai dengan karakteristik soal PISA dengan level soal sesuai dengan level 5, dan sesuai dengan karakteristik soal pengayaan. Dari segi konstruk, soal telah mengembangkan kemampuan literasi matematika, kaya dengan konsep, sesuai dengan level siswa kelas VII SMP, dan mengundang pengembangan konsep lebih jauh. Yang terakhir, soal telah baik dari segi bahasa yaitu tidak berbelit-belit, tidak mengandung penafsiran ganda, batasan pertanyaan dan jawaban jelas.

Selain uji validitas secara kualitatif, soal juga telah diujikan secara kuantitatif. Hasil analisis butir soal menunjukkan bahwa soal dinyatakan tidak valid. Setelah dianalisis hasil angket dan wawancara siswa, diketahui bahwa penyebab ketidakvalidan soal bukan karena bahasa atau kalimat soal yang tidak dimengerti siswa, melainkan kurangnya pemahaman konsep siswa mengenai materi yang telah dipelajari. Di samping itu, ketidakvalidan soal juga disebabkan fluktuasi skor jawaban soal yang terlalu besar, seperti pada soal pilihan ganda. Maka dari itu, diputuskan untuk tidak membuang soal, melainkan merevisi skor jawaban soal pada rubrik penilaian. Soal tersebut juga telah diuji tingkat reliabilitasnya. Hasil koefisien reliabilitas dari soal yang diujicobakan yaitu sebesar 0,698. Dengan hasil koefisien yang telah didapat, soal dinyatakan memiliki reliabilitas yang tinggi.

Soal yang dikembangkan juga telah dinyatakan praktis berdasarkan hasil pada tahap one-to-one dan small group. Pada pelaksanaan one-to-one, masih terdapat siswa yang mengalami kesulitan untuk memahami maksud dari soal. Dengan demikian dilakukan revisi redaksi kalimat pada soal. Hasil revisi tahap one-to-one diujicobakan kembali pada tahap small group, dan terlihat bahwa sebagian besar siswa dapat menggunakan perangkat soal dengan baik. Hal ini berarti soal yang dikembangkan sesuai dengan cara berpikir siswa dan konteks yang digunakan pada soal telah diketahui 
siswa sehingga dapat dipahami siswa dengan baik tanpa menimbulkan penafsiran yang beragam.

Berikut ini pembahasan soal dan hasil jawaban siswa pada tahap field test untuk melihat proses siswa menyelesaikan soal dengan strateginya masing-masing. Soal yang dikembangkan memerlukan kemampuan pemahaman siswa terhadap pertanyaan dan gambar yang disajikan pada keadaan sebenarnya. Dalam menyelesaikan soal tersebut, siswa melakukan penalaran dan perencanaan strategi penyelesaian yang efektif. Siswa juga harus menerapkan konsep luas bangun datar persegi panjang dan mengestimasi dengan tepat jumlah pembeli yang mungkin ada pada suatu area dengan luas tertentu, sehingga siswa sampai pada kesimpulan pilihan jawaban yang benar.

Sesuai dengan indikator soal level 5 dan karakteristik soal pengayaan, soal ini menuntut siswa bekerja secara efektif dengan model dan situasi yang kompleks dimana terdapat gambar dari sekelompok orang yang sedang mengantri dan siswa diminta untuk menaksir banyak orang yang ada di area tersebut tentunya dengan bantuan informasiinformasi yang diberikan yaitu bentuk dan ukuran dari tempat antri tersebut. Siswa juga memilih, membandingkan dan mengevaluasi strategi penyelesaian yang dipilih dalam mengestimasi jumlah orang yang diperkirakan sesuai dengan area mengantri seperti yang diperlihatkan pada soal. Dalam melakukan estimasi, siswa juga harus berpikir dan bernalar yang baik dan serta secara tepat menghubungkan pengetahuan dan keterampilan matematika yang dimiliki.

Sebanyak 55\% siswa dapat menjawab soal tersebut dengan benar dengan penjelasan yang tepat, $45 \%$ siswa memilih jawaban yang tepat tetapi tidak disertai penjelasan yang benar atau bahkan tidak memberikan penjelasan, dan selebihnya menjawab salah atau tidak menjawab.

\section{SIMPULAN DAN SARAN}

Berdasarkan hasil dan pembahasan mengenai pengembangan soal matematika model PISA level 5 untuk program pengayaan, maka dapat disimpulkan bahwa telah dihasilkan soal matematika model PISA level 5 yang valid dan praktis. Kevalidan soal telah diujikan secara kualitatif dan kuantitatif. Validasi kualitatif ditunjukkan dari hasil penilaian validator pada tahap expert review yang menyatakan bahwa soal telah baik dari segi konten, konstruk dan bahasa. Uji validitas secara kuantitatif pada tahap small 
group menunjukkan bahwa soal tersebut tidak valid. Setelah dilakukan analisis terhadap hasil jawaban siswa, angket dan wawancara secara langsung ditemukan beberapa penyebab ketidakvalidan soal. Diketahui bahwa ketidakvalidan soal tidak disebabkan bahasa atau kalimat soal yang tidak jelas, melainkan kurangnya pemahaman konsep siswa mengenai materi yang ada pada soal. Penyebab lainnya yaitu fluktuatif skor jawaban yang terlalu besar. Sehingga diputuskan untuk tidak membuang soal, melainkan merevisi jawaban pada rubrik penskoran. Soal juga telah dinyatakan memiliki tingkat reliabilitas yang tinggi yaitu sebesar 0,698. Sedangkan untuk kepraktisan, para ahli/praktisi telah menyatakan bahwa soal tersebut tepat untuk diberikan pada siswa kelas VII. Hal ini juga terlihat pada tahap one-to-one dan small group bahwa siswa dapat menggunakan perangkat soal dengan baik. Setelah dinyatakan valid, praktis dan reliabel, soal diujikan pada tahap field test yaitu sebanyak 20 orang siswa menjawab soal model PISA yang dikembangkan untuk mengetahui apakah soalsoal tersebut dapat digunakan pada situasi yang sebenarnya.

Berdasarkan hasil penelitian dan kesimpulan, maka sekiranya hasil penelitian ini dapat menjadi bahan masukan pada proses pembelajaran di sekolah. Yaitu sebaiknya siswa diberikan soal-soal model PISA seperti yang telah dikembangkan pada penelitian ini, agar siswa terbiasa menerapkan pengetahuan dan pemahaman konsep yang ia miliki dalam menjawab soal sehingga siswa berkompeten untuk bersaing di tingkat international. Selain itu juga bagi peneliti lain dalam mengembangkan soal model PISA pada program pengayaan untuk jenjang sekolah menengah pertama.

\section{DAFTAR PUSTAKA}

Barczi, Krisztina. (2008). "A study on how Hungarian students solve problems that are unusual for them." Handbook of Mathematics Teaching Improvement:

Professional Practices that address PISA.

Beecher, M., \& Sweeny, S. M. (2008).Closing the achievement gap with curriculum enrichment and differentiation: One school's story.Journal of Advanced Academics, 19(3), 502-530.

Depdiknas. (2008). Sistem Penilaian KTSP: Panduan Penyelenggaraan Pembelajaran Pengayaan.

Djaali \& Muljono, P. (2008). Pengukuran dalam Bidang Pendidikan. Jakarta: PT. Grasindo. 
Edo, S. I., Hartono, Y., Ilma, R. (2012). Investigating Secondary School Students' Difficulties in Modelling Problems PISA-Model level 5 and 6. Journal on Mathematics Education (IndoMS-JME), 3(2), 151-168.

Forster, M. (2004).Higher Order Thinking Skills.Research Development ,11, 2-6.

Gijlers, H., \& De Jong, T. (2005). The relation between prior knowledge and students' collaborative discovery learning processes. Journal of Research in Science Teaching, 42(3), 264-282.

Kamaliyah. (2012). Developing the Sixth Level of PISA-Like Mathematics Problem for SecondarySchool Student. Journal on Mathematics Education (IndoMS-JME), 3(2), 169-188.

Kemdikbud.(2013). Materi Pelatihan Guru Implementasi Kurikulum 2013 SMP/MTs Matematika.Badan Pengembangan Sumber Daya Manusia Pendidikan dan Kebudayaan dan Penjaminan Mutu Pendidikan Kementerian Pendidikan dan Kebudayaan. Jakarta: Kemdikbud.

Lalley, J. P., \&Gentile, J. R. (2003).Classroom assessment and grading to assure mastery. Theory Into Practice, 48(1), 28-35.

Lutfianto, M. (2013) Unfinished Student Answer In Pisa Mathematics Contextual Problem. In: Zulkardi(Eds). The First South East Asia Design/ Development Research (SEA-DR) International Conference, April 22nd-23rd, 2013, Unsri, Palembang.

Mangelep, N. O. (2013). Pengembangan Soal Matematika pada Kompetensi Proses Koneksi dan Refleksi PISA.Jurnal Edukasi Matematika (Edumat), 4(7), 437510.

McAllister, B. A., \& Plourde, L. A. (2008). Enrichment Curriculum: Essential for Mathematically Gifted Students. Education, 129(1), 40-49.

Novita, R., Zulkardi, Hartono, Y. (2012). Exploring Primary Student's Problem-Solving Abillity. Journal on Mathematics Education (IndoMS-JME), 3(2), 133-150.

OECD. (2013). PISA 2012 Assessment and Analytical Framework: Mathematics, Reading, Science, Problem Solving and Financial Literacy. Paris: OECD

Plomp, T. (2013). Educational design research: An introduction. An introduction to educational design research, 22-26.

Renzulli, J., \& Reis, S. (2007). A technology based program that matches enrichment resources with student strengths. International Journal of Emerging Technologies in Learning (iJET), 2(3). 
Rizta, A., Zulkardi, Z., \& Hartono, Y. (2013).Pengembangan Soal Penalaran Model TIMSS Matematika SMP. Jurnal Penelitian \& Evaluasi Pendidikan, 17(2).

Rule, A. C., Schneider, J. S., Tallakson, D. A., \& Highnam, D. (2012). Creativity and Thinking Skills Integrated into a Science Enrichment Unit on Flooding. Creative Education, 3(8), 1371-1379.

Stacey, K. (2011). The View of Mathematical Literacy in Indonesia.Journal on Mathematics Education (IndoMS-JME), 2(2) , 1-24.

Tessmer, M. (1993). Planning and conducting formative evaluations: Improving the quality of education and training. London: Kogan Page.

Widjaja, W. (2011)Towards mathematical literacy in the 21 st century: perspectives from Indonesia. Southeast Asian mathematics education journal, 1(1), 75-84.

Zulkardi. (2002). Developing a Learning Environment on Realistic Mathematics Education for Indonesian Student Teachers. Dissertation.University of Twente, Enschede.The Netherland. 